\title{
Improved Healing after Non-Surgical Periodontal Therapy Is Associated with Higher Protein Intake in Patients Who Are Non-Smokers
}

\author{
David W. Dodington ${ }^{1}$, Hannah E. Young ${ }^{1}\left(\mathbb{D}\right.$, Jennifer R. Beaudette ${ }^{1}$, Peter C. Fritz ${ }^{1,2}$ and Wendy E. Ward ${ }^{1, *(\mathbb{D})}$ \\ 1 Department of Kinesiology, Faculty of Applied Health Sciences, Brock University, \\ St. Catharines, ON L2S 3A1, Canada; david.dodington@mail.utoronto.ca (D.W.D.); \\ hy19nt@brocku.ca (H.E.Y.); jbeaudette3@gmail.com (J.R.B.); drpeterfritz@me.com (P.C.F.) \\ 2 Periodontal Wellness and Implant Surgery Clinic, Fonthill, ON L0S 1E5, Canada \\ * Correspondence: wward@brocku.ca
}

\section{check for} updates

Citation: Dodington, D.W.; Young, H.E.; Beaudette, J.R.; Fritz, P.C.; Ward, W.E. Improved Healing after Non-Surgical Periodontal Therapy Is Associated with Higher Protein Intake in Patients Who Are Non-Smokers. Nutrients 2021, 13, 3722. https://doi.org/10.3390/ nu13113722

Academic Editors: Kirstin Vach and Johan Peter Woelber

Received: 25 September 2021

Accepted: 19 October 2021

Published: 22 October 2021

Publisher's Note: MDPI stays neutral with regard to jurisdictional claims in published maps and institutional affiliations.

Copyright: (c) 2021 by the authors. Licensee MDPI, Basel, Switzerland. This article is an open access article distributed under the terms and conditions of the Creative Commons Attribution (CC BY) license (https:/ / creativecommons.org/licenses/by/ $4.0 /)$.

\begin{abstract}
The aim of this study was to determine whether a relationship between periodontal healing and protein intake exists in patients undergoing non-surgical treatment for periodontitis. Dietary protein intake was assessed using the 2005 Block food frequency questionnaire in patients with chronic generalized periodontitis undergoing scaling and root planing ( $n=63$ for non-smokers, $n=22$ for smokers). Protein intake was correlated to post-treatment probing depth using multiple linear regression. Non-smoking patients who consumed $\geq 1 \mathrm{~g}$ protein $/ \mathrm{kg}$ body weight/day had fewer sites with probing depth $\geq 4 \mathrm{~mm}$ after scaling and root planing compared to patients with intakes $<1 \mathrm{~g}$ protein $/ \mathrm{kg}$ body weight/day (11 \pm 2 versus $16 \pm 2, p=0.05)$. This relationship was strengthened after controlling for baseline probing depth, hygienist and time between treatment and follow-up (10 \pm 2 versus $16 \pm 1, p=0.018$ ) and further strengthened after controlling for potential confounders including age, sex, body mass index, flossing frequency, and bleeding on probing ( $8 \pm 2$ versus $18 \pm 2, p<0.001)$. No associations were seen in patients who smoked. Consuming $\geq 1 \mathrm{~g}$ protein $/ \mathrm{kg}$ body weight/day was associated with reductions in periodontal disease burden following scaling and root planing in patients who were non-smokers. Further studies are needed to differentiate between animal and plant proteins.
\end{abstract}

Keywords: periodontitis; periodontal diseases; scaling and root planning; diet; dietary protein

\section{Introduction}

It is estimated that $70 \%$ of Canadians will experience periodontal disease in their lifetime [1]. Globally, the prevalence of periodontal disease is $11.2 \%$, and severe periodontitis is the sixth most prevalent disease worldwide [2,3]. In the United States, the prevalence of periodontitis is $38 \%$ for adults over 30 years of age, and it increases to $64 \%$ in those over 65 years $[4,5]$. Periodontal disease has also been associated with numerous chronic illnesses including obesity, diabetes, metabolic syndrome, and rheumatoid arthritis [3,6,7]. While there are many known risk factors for periodontal disease, such as diet and smoking, there is a paucity of data on the roles of these factors in periodontal healing after scaling and root planing (SRP), the first-line non-surgical treatment modality for periodontitis [8]. Healing after SRP is dependent on the resolution of inflammation and reactive oxygen species and can result in reductions in probing depth (PD) and bleeding on probing (BOP) due to the repair and regeneration of damaged tissues $[9,10]$. SRP followed by routine periodontal maintenance appointments can prevent disease progression and ultimately, tooth loss. Tooth loss can have negative effects on speech, food intake, self-esteem and quality of life, and is independently associated with several chronic systemic inflammatory diseases [7]. Thus, it is important to understand the factors that may support periodontal healing post-SRP. 
Smoking is a risk factor for numerous chronic diseases through increased inflammation and/or a compromised inflammatory response [11,12] and is a variable of interest due to its known negative effects on periodontal health [13]. Negative associations between smoking and periodontal bone loss, BOP, PD and clinical attachment loss have been found in patients following periodontal treatment [13-15]. While there is evidence to suggest diet is a risk factor for periodontal disease, this evidence is much weaker. Some associations are observed between periodontal health and nutrients with known anti-inflammatory, osteogenic and antioxidant activity [16-21] — these include calcium, vitamin C, flavonoids and omega 3 fatty acids. A previous study by our team reported associations between diet and healing post-SRP and found intakes of fruits and vegetables, $\beta$-carotene, vitamin $C, \alpha$ tocopherol and long chain omega- 3 fatty acids (EPA, DHA) to be positively associated with periodontal healing in patients who did not smoke [18]. There was no association between these same components in individuals who currently smoked [18]. It was hypothesized that the lack of an association was due to the negative effect of smoking on the periodontium, though it may also have been due to a small sample size.

With the paucity of data on protein intake and periodontal healing, protein was the primary nutrient of interest in the present study. Periodontal disease is most prevalent in adults over 65 years of age and has been associated with age-related diseases [22,23]. This, along with the fact that protein is the most important macronutrient for supporting immune function and wound healing [24], provided a rationale to determine if there is an association between higher protein intakes and periodontal healing. Of note, several organizations advocate that protein intakes of 1.0 to $1.5 \mathrm{~g} / \mathrm{kg}$ body weight/day rather than the current recommended dietary allowance (RDA) for protein intake $(0.8 \mathrm{~g} / \mathrm{kg}$ body weight/day) are more appropriate for older adults ( $\geq 65$ years) to reduce sarcopenia and its resultant loss in quality of life [25-27]. Sarcopenia is defined as a reduction in muscle mass and muscle function that occurs with aging $[25,26]$. The destruction of alveolar bone tissue is a prominent feature of periodontal disease; sufficient protein intake is associated with higher bone mineral density and slower rates of bone loss, again supporting a potential role of protein in periodontal healing $[21,27,28]$. Protein also has known anabolic effects on bone and may increase calcium absorption from the gut, leading to increased bone mineralization [28]. Moreover, two recent studies suggest a significant relationship between increased dairy consumption and decreased prevalence of periodontal disease [29,30]. Finally, a study in a rat model of periodontal disease found that consuming a higher level of milk basic protein (MBP) (1\% versus $0.2 \%$ ) supported greater recovery of alveolar bone that was lost as a result of previous ligature placement [31].

Given the widespread interest in higher protein intakes and health and indirect evidence suggesting a potential benefit in periodontal healing, the primary objective of this study was to determine whether the intake of dietary protein $(\geq 1 \mathrm{~g} / \mathrm{kg}$ body weight/day) was associated with a reduction in periodontal disease burden (i.e., fewer sites with $\mathrm{PD} \geq 4 \mathrm{~mm}$ ) following non-surgical treatment of periodontitis.

\section{Materials and Methods}

\subsection{Study Population and Design}

The data presented in this study are a retrospective analysis from a patient cohort initially investigated to study the relationship between fruits and vegetables, antioxidants, vitamins and omega-3 fatty acid intake and healing following SRP [18]. The study took place at a specialty periodontal clinic (Fonthill, ON, Canada) between January 2013 and July 2014. All patients undergoing SRP during this time were invited to participate in the study. Patients were excluded from the study analysis if they did not meet the requirements for chronic generalized periodontitis set by the American Academy of Periodontology (PD of $\geq 4 \mathrm{~mm}$ in at least $30 \%$ of sites) [32]. While a new periodontal classification system was developed in 2017, after this study was conducted, and the term 'chronic periodontitis' is no longer used, reporting the number and proportion of teeth with $\mathrm{PD} \geq 4 \mathrm{~mm}$ remains a clinically meaningful periodontal measure in the new classification system [33]. During the 
enrolment visit, a comprehensive baseline dental examination including medical/dental history and periodontal charting was completed (see Section 2.2, Periodontal Examination, for more details). Full mouth SRP was then performed by one of four calibrated hygienists using hand and ultrasonic instruments as necessary. Individualized oral hygiene instructions were also provided to all patients. Participants were provided with a food frequency questionnaire (FFQ) to be completed at home and returned the follow-up appointment. Follow-up occurred between 8 and 16 weeks after SRP and included a complete periodontal examination. The Bioscience Research Ethics Board at Brock University approved the study protocol and all participants provided written informed consent. This trial was registered at clinicaltrials.gov (accessed on 18 October 2021) as NCT02291835.

\subsection{Periodontal Examination}

Baseline and follow-up periodontal charting included measurement of PD, BOP and plaque index (PI). PD was measured using a periodontal probe as the distance from the gingival margin to the bottom of the periodontal pocket at six sites per tooth (mesiobuccal, buccal, distobuccal, mesiolingual, lingual, and distolingual) on all teeth present, and the number of sites $\geq 4 \mathrm{~mm}$ were counted. Teeth to be extracted were not included in the count. BOP and PI were assessed by visual inspection after probing, and PI was measured using the $\mathrm{O}^{\prime}$ Leary Plaque Index [34]. The baseline examinations were all performed by the same periodontist (P.C.F.) and occurred 1 to 19 weeks prior to SRP. Follow-up examinations were performed by one of four hygienists at 8 to 16 weeks post-SRP. Prior to the study, the hygienists were calibrated to apply $25 \mathrm{~N}$ of pressure when probing by repeated probing simulations against an electronic scale.

\subsection{Diet Assessment}

Nutrient intakes were assessed using the 2005 Block FFQ, which has been previously validated against multiple diet records [35] (https: / / www.nutritionquest.com/assessment/ list-of-questionnaires-and-screeners / (accessed on 21 October 2021)). The FFQ queried 110 food items for frequency (never, a few times a year, once per month, 2-3 times per month, once per week, 2 times per week, 3-4 times per week, 5-6 times per week, every day) and portion size. Portion size pictures were provided to enhance the accuracy of quantification. Nutrient intake estimates were calculated using a database of nutrient values derived from the Canadian Nutrient File. Assessment of reporting accuracy in this cohort has been previously published [18]. Nutrient intakes were energy adjusted and standardized to a $2000 \mathrm{Kcal}$ diet using the residual method [36]. Protein intake was expressed in grams per kilogram of body weight and participants were classified by protein intake level ( $<1 \mathrm{~g} / \mathrm{kg}$ body weight/day or $\geq 1 \mathrm{~g} / \mathrm{kg}$ body weight/day). The $1 \mathrm{~g} / \mathrm{kg}$ bodyweight/day cut-off was chosen due to evidence suggesting protein intakes $\geq 1 \mathrm{~g} / \mathrm{kg}$ body weight/day may be more appropriate for older adults ( $>65$ years) [25-27].

\subsection{Assessment of Covariates}

Self-reported age, sex, health conditions, medication use and smoking status (never, former or current) were recorded from the patient's medical history form. Dental hygiene information was gathered by a hygienist and included brushing and flossing frequency, electronic toothbrush use, frequency of professional dental cleaning and any previous periodontal therapy. Participants also met with a study nurse during their initial visit and had their height and body weight measured (Health-O-Meter Professional) to calculate their BMI. Blood was also drawn at this time for the measurement of serum 25-hydroxyvitamin D, which was analyzed by a third-party provider (Life Labs, Thorold, ON, Canada) using the Liaison chemiluminescence system (DiaSorin Inc., Mississauga, Canada). The laboratory participates in the Vitamin D External Quality Assessment Scheme (DEQAS). 


\subsection{Statistical Analysis}

Patients were stratified by smoking status for two main reasons: i. patients who smoke are known to have compromised healing after SRP $[15,37]$ and ii. no associations between periodontal health and any of the previously analyzed nutrient intakes was previously observed in patients who smoke [18]. Descriptive statistics and nutrient intakes were compared between the protein intake groups using an independent sample $t$ test for continuous variables and chi-square test for categorical variables. When the expected cell count was $<5$ for categorical variables, Fisher's exact test was used in place of the chi-square test. Due to the small sample size and the violation of the assumption of normality in the group of patients who smoked, a Mann-Whitney U Test was used instead of the independent sample $\mathrm{t}$ test. The relationship between protein intake and periodontal healing was assessed by multiple linear regression using PD as a continuous dependent variable. Protein intake was entered into the model as a dichotomous variable ( $<1$ versus $\geq 1 \mathrm{~g}$ protein $/ \mathrm{kg} /$ day), first in an unadjusted model, then in subsequent models with adjustment for covariates. All models were assessed for normality of residuals and multicollinearity. Data were analyzed with SPSS v.20 (IBM, Inc., Armonk, NY, USA), and statistical significance was defined as $p<0.05$.

\section{Results}

\section{Main Findings}

In total, 129 patients were recruited for the study (Figure 1). Of those, 17 patients were lost to follow-up, 11 did not return within the 16-week follow-up period, and $3 \mathrm{did}$ not complete the food frequency questionnaire and were thus excluded from the analysis. Subsequently, 12 did not meet the criteria for chronic generalized periodontitis and were excluded. One additional patient was excluded as their body weight was not measured, so protein intake per $\mathrm{kg}$ of bodyweight could not be calculated. There were no differences in age, sex, BMI, smoking status, baseline clinical outcomes, or serum 25 -hydroxyvitamin D concentration between those included and those excluded from the analysis (Table S1).

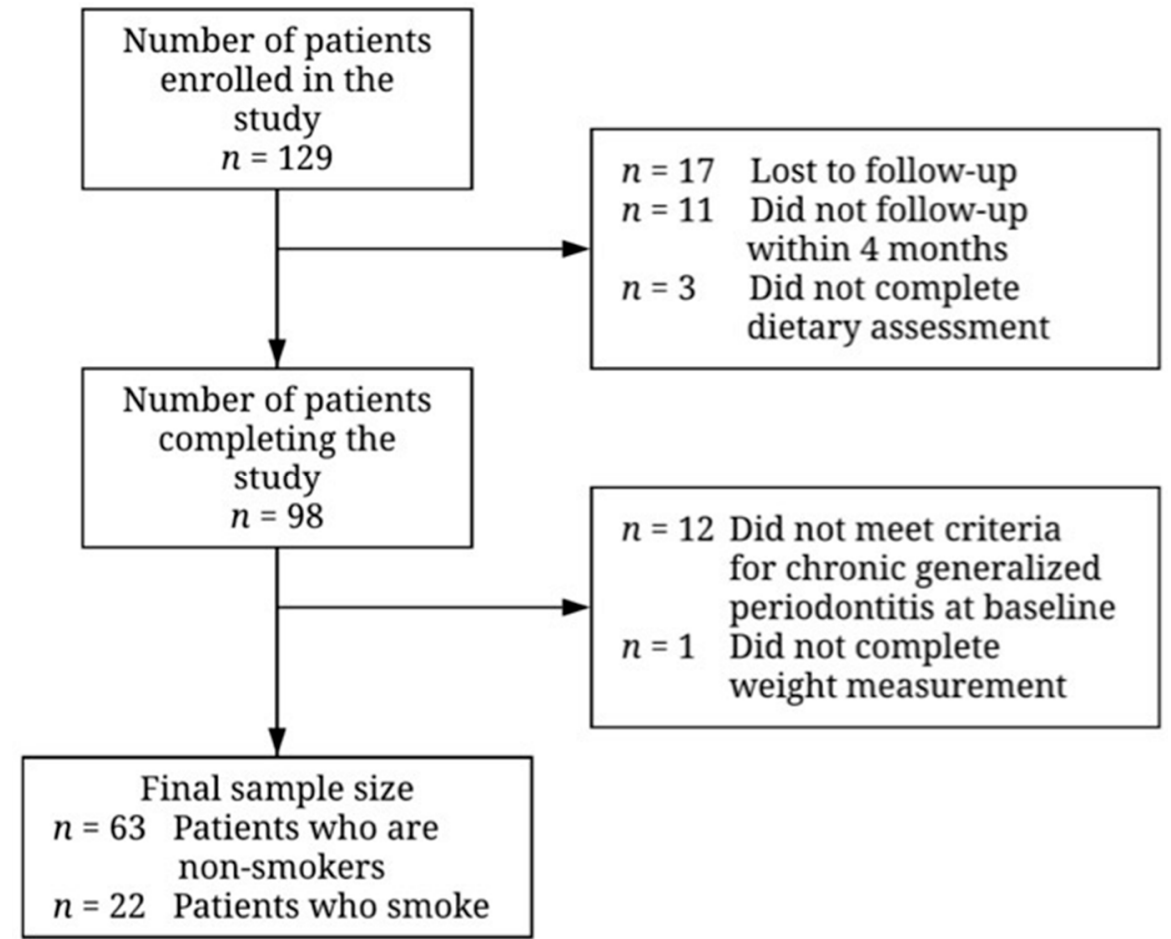

Figure 1. Flowchart illustrating recruitment and final sample size for patients undergoing nonsurgical periodontal therapy. Reasons for exclusion of participants are given to the right of the arrows denoting the transitions between stages. 
Participant characteristics by level of protein intake and smoking status are shown in Table 1. Regardless of smoking status, participant age and comorbidities did not differ between the two levels of protein intake. For patients who were non-smokers, former smoking status did not differ based on protein intake. For both non-smokers and smokers, the $\geq 1 \mathrm{~g} / \mathrm{kg}$ body weight/day protein group had significantly more female participants and they had a lower average BMI. In terms of dental hygiene, there were no differences in brushing frequency, electric toothbrush use, professional cleaning frequency and previous periodontal therapy based on protein intake levels in both the smoking and non-smoking groups. Patients who were non-smokers and consumed $\geq 1 \mathrm{~g} / \mathrm{kg} /$ day of protein reported significantly higher flossing frequencies compared to those who consumed $<1 \mathrm{~g} / \mathrm{kg}$ body weight/day of protein; however, this difference was not observed in patients who smoked.

Table 1. Descriptive statistics and clinical parameters of patients undergoing non-surgical periodontal therapy grouped by protein intake and current smoking status ${ }^{1}$.

\begin{tabular}{|c|c|c|c|c|c|c|}
\hline & \multicolumn{3}{|c|}{ Patients Who Did Not Smoke } & \multicolumn{3}{|c|}{ Patients Who Did Smoke } \\
\hline & \multicolumn{2}{|c|}{$\begin{array}{c}\text { Protein Intake } \\
\text { g/kg Body Weight/Day }\end{array}$} & \multirow{3}{*}{$p$ Value } & \multicolumn{2}{|c|}{$\begin{array}{c}\text { Protein Intake } \\
\text { g/kg Body Weight/Day }\end{array}$} & \multirow{3}{*}{$p$ Value } \\
\hline & $<1$ & $\geq \mathbf{1}$ & & $<1$ & $\geq 1$ & \\
\hline & $n=34$ & $n=29$ & & $n=10$ & $n=12$ & \\
\hline \multicolumn{7}{|c|}{ Patient Characteristics } \\
\hline Male & $25(73 \%)$ & $8(28 \%)$ & $<0.001$ & $7(70 \%)$ & $2(17 \%)$ & 0.027 \\
\hline Female & $9(27 \%)$ & $21(72 \%)$ & $<0.001$ & $3(30 \%)$ & $10(83 \%)$ & 0.027 \\
\hline Age (years) & $57 \pm 10$ & $61 \pm 13$ & 0.10 & $54 \pm 8$ & $52 \pm 7$ & 0.72 \\
\hline $\mathrm{BMI}\left(\mathrm{kg} / \mathrm{m}^{2}\right)$ & $31.8 \pm 5.0$ & $26.6 \pm 3.8$ & $<0.001$ & $31.8 \pm 6.1$ & $24.6 \pm 4.2$ & 0.004 \\
\hline Former smokers & $15(44 \%)$ & $18(62 \%)$ & 0.16 & - & - & - \\
\hline \multicolumn{7}{|c|}{ Comorbidities } \\
\hline Diabetes & $4(12 \%)$ & $2(7 \%)$ & 0.68 & $1(10 \%)$ & $1(8.3 \%)$ & 1.00 \\
\hline HTN or CAD & $14(41 \%)$ & $10(35 \%)$ & 0.59 & $3(30 \%)$ & $2(17 \%)$ & 0.62 \\
\hline Osteoporosis & $1(3 \%)$ & $5(17 \%)$ & 0.09 & 0 & 0 & - \\
\hline \# of medications & $3 \pm 3$ & $3 \pm 4$ & 0.75 & $2 \pm 1$ & $1 \pm 2$ & 0.25 \\
\hline \multicolumn{7}{|c|}{ Dental hygiene } \\
\hline Brushing (times / day) & 2.2. \pm 0.6 & $2.4 \pm 1.1$ & 0.37 & $1.0 \pm 0.7$ & $2.3 \pm 0.75$ & 0.35 \\
\hline Flossing (times/week) & $2.7 \pm 4.4$ & $5.3 \pm 3.6$ & 0.016 & $2.4 \pm 4.7$ & $5.0 \pm 6.1$ & 0.069 \\
\hline Electric toothbrush use & $11(32 \%)$ & $10(35 \%)$ & 0.83 & $3(27 \%)$ & $3(25 \%)$ & 1.00 \\
\hline Cleanings (months) & $5 \pm 3$ & $5 \pm 3$ & 0.54 & $5 \pm 3$ & $7 \pm 6$ & 0.67 \\
\hline Previous therapy & $10(29 \%)$ & $8(28 \%)$ & 0.89 & $3(30 \%)$ & $3(25 \%)$ & 1.00 \\
\hline \multicolumn{7}{|c|}{ Baseline clinical outcomes } \\
\hline Number of teeth & $25 \pm 4$ & $25 \pm 4$ & 0.81 & $25 \pm 4$ & $26 \pm 2$ & 0.25 \\
\hline PD (\# sites $\geq 4 \mathrm{~mm}$ ) & $93 \pm 37$ & $93 \pm 33$ & 0.96 & $102 \pm 39$ & $107 \pm 34$ & 0.77 \\
\hline BOP (\# sites) & $76 \pm 46$ & $77 \pm 50$ & 0.92 & $79 \pm 61$ & $73 \pm 43$ & 0.77 \\
\hline Plaque index $(\%)$ & $78 \pm 27$ & $67 \pm 30$ & 0.19 & $83 \pm 24$ & $57 \pm 37$ & 0.080 \\
\hline Follow-up time (days) & $74 \pm 17$ & $78 \pm 15$ & 0.37 & $79 \pm 17$ & $80 \pm 16$ & 0.92 \\
\hline \multicolumn{7}{|c|}{ Follow-up clinical outcomes } \\
\hline Number of teeth & $24 \pm 4$ & $24 \pm 5$ & 0.95 & $24 \pm 4$ & $26 \pm 3$ & 0.35 \\
\hline PD (\# sites $\geq 4 \mathrm{~mm}$ ) & $16 \pm 11$ & $11 \pm 8$ & 0.05 & $22 \pm 21$ & $20 \pm 15$ & 1.00 \\
\hline BOP (\# sites) & $8 \pm 9$ & $3 \pm 6$ & 0.009 & $13 \pm 18$ & $4 \pm 7$ & 0.069 \\
\hline Plaque index $(\%)$ & $36 \pm 19$ & $28 \pm 25$ & 0.14 & $47 \pm 26$ & $30 \pm 25$ & 0.50 \\
\hline
\end{tabular}


Table 1. Cont.

\begin{tabular}{|c|c|c|c|c|c|c|}
\hline & \multicolumn{3}{|c|}{ Patients Who Did Not Smoke } & \multicolumn{3}{|c|}{ Patients Who Did Smoke } \\
\hline & \multicolumn{2}{|c|}{$\begin{array}{c}\text { Protein Intake } \\
\text { g/kg Body Weight/Day }\end{array}$} & \multirow{3}{*}{$p$ Value } & \multicolumn{2}{|c|}{$\begin{array}{c}\text { Protein Intake } \\
\text { g/kg Body Weight/Day }\end{array}$} & \multirow{3}{*}{$p$ Value } \\
\hline & $<1$ & $\geq \mathbf{1}$ & & $<1$ & $\geq \mathbf{1}$ & \\
\hline & $n=34$ & $n=29$ & & $n=10$ & $n=12$ & \\
\hline \multicolumn{7}{|c|}{ Nutritional intake and status } \\
\hline Calories (Kcal/day) & $1625 \pm 586$ & $1583 \pm 649$ & 0.79 & $1828 \pm 530$ & $1525 \pm 674$ & 0.28 \\
\hline Protein (g/day) & $79 \pm 10$ & $88 \pm 9$ & $<0.001$ & $69 \pm 13$ & $84 \pm 13$ & 0.025 \\
\hline Carbohydrate (g/day) & $244 \pm 34$ & $230 \pm 37$ & 0.14 & $231 \pm 51$ & $227 \pm 33$ & 0.72 \\
\hline Fats (g/day) & $76 \pm 12$ & $78 \pm 13$ & 0.43 & $77 \pm 12$ & $80 \pm 18$ & 1.00 \\
\hline $\mathrm{EPA}+\mathrm{DHA}$ (mg/day) & $320 \pm 463$ & $380 \pm 365$ & 0.58 & $99 \pm 61$ & $253 \pm 163$ & 0.021 \\
\hline Vitamin C (mg/day) & $130 \pm 51$ & $129 \pm 37$ & 0.90 & $105 \pm 61$ & $137 \pm 73$ & 0.25 \\
\hline 25-OH-D (nmol/L) & $59 \pm 21$ & $70 \pm 25$ & 0.074 & $44 \pm 12$ & $57 \pm 21$ & 0.159 \\
\hline
\end{tabular}

${ }^{1}$ All values are means \pm SDs for continuous variables and counts (\%) for categorical variables. Non-standard abbreviations: HTN, hypertension; CAD, coronary artery disease; $\mathrm{PD}$, probing depth; BOP, bleeding on probing; EPA, eicosapentaenoic acid; DHA, docosahexaenoic acid; 25-OH-D, 25-hydroxyvitamin D.

Importantly, there were no differences in periodontal outcomes between protein intake groups at baseline, including the number of teeth, PD, BOP and PI, as well as the time between treatment and follow-up regardless of smoking status. By design, protein intakes differed between groups. Other nutritional intakes, including total energy, total carbohydrate, total fat, omega-3 fatty acid, vitamin $C$ intakes and serum 25-hydroxyvitamin $\mathrm{D}$ were not significantly different between the two levels of dietary protein intake in those who did not smoke. In patients who smoked, only omega-3 fatty acid intake was significantly higher in those with protein intakes $\geq 1 \mathrm{~g} / \mathrm{kg}$ body weight/day.

In the unadjusted regression analysis, non-smoking patients who consumed $\geq 1 \mathrm{~g} / \mathrm{kg}$ body weight/day of protein had fewer sites with $\mathrm{PD} \geq 4 \mathrm{~mm}$ at the time of follow-up compared to those who consumed $<1 \mathrm{~g} / \mathrm{kg} /$ day of protein. This difference was borderline significant $(11 \pm 2$ versus $16 \pm 2, p=0.05)$ (Model 1, Table 2 and Figure $2 \mathrm{a}$ ). To improve the fit of the model, additional study design factors were considered in the regression model. This included the patient's baseline PD, the hygienist performing their treatment and the time between treatment and follow-up.

$<1 \mathrm{~g}$ protein $/ \mathrm{kg} /$ day

$\square \geq 1 \mathrm{~g}$ protein $/ \mathrm{kg} /$ day

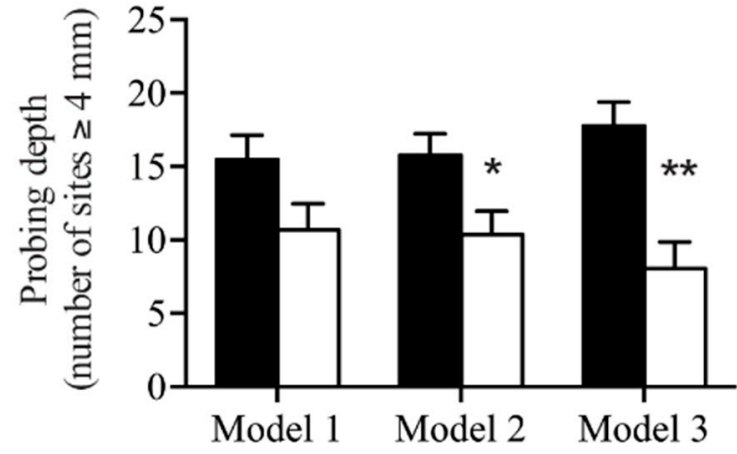

(a)

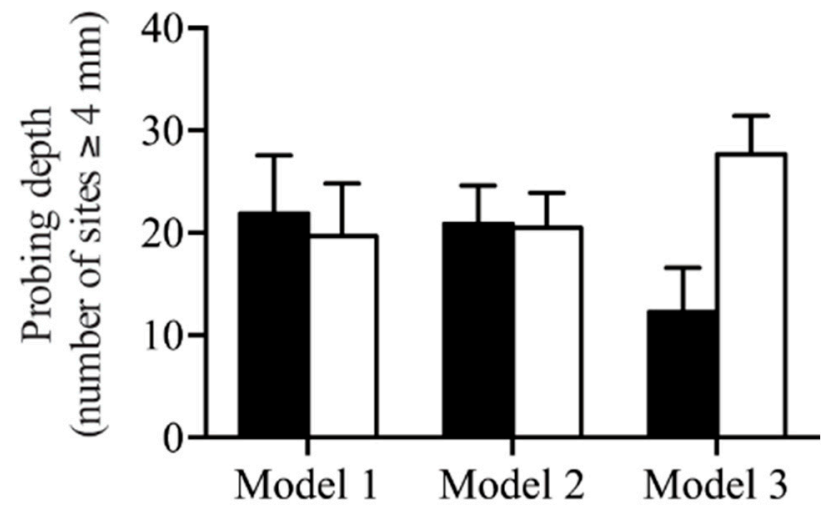

(b)

Figure 2. Comparison of dietary protein levels with probing depth after non-surgical periodontal therapy in patients who (a) did not smoke and (b) did smoke. Model 1 is unadjusted. Model 2 adjusted for baseline probing depth, hygienist and time between treatment and follow-up. Model 3 adjusted for variables in Model 2 plus age, sex, BMI, flossing frequency and bleeding on probing. Data presented are estimated marginal means \pm SEM. * Indicates a significant difference between groups $(p<0.05),{ }^{* *}$ indicates a significant difference between the two levels of protein intake $(p<0.01)$. 
Table 2. Multiple linear regression of probing depth sites $>4 \mathrm{~mm}$ in patients after non-surgical periodontal therapy who did not smoke ${ }^{1}$.

\begin{tabular}{|c|c|c|c|c|c|c|}
\hline & \multicolumn{2}{|c|}{ Model 1} & \multicolumn{2}{|l|}{ Model 2} & \multicolumn{2}{|c|}{ Model 3} \\
\hline & $B(95 \%$ CI $)$ & $p$ & $B(95 \%$ CI $)$ & $p$ & $B(95 \% \mathrm{CI})$ & $p$ \\
\hline $\begin{array}{l}\text { Protein intake } \\
<1 \mathrm{~g} / \mathrm{kg} \text { body } \\
\text { weight/day }\end{array}$ & Reference & & Reference & & Reference & \\
\hline $\begin{array}{c}\geq 1 \mathrm{~g} / \mathrm{kg} \text { body } \\
\text { weight/day }\end{array}$ & $-4.8(-9.6,0.0)$ & 0.050 & $-5.4(-9.9,-1.0)$ & 0.018 & $-9.7(-15.5,-3.9)$ & 0.001 \\
\hline \multicolumn{7}{|l|}{ Hygienist } \\
\hline Hygienist 1 & & & Reference & & Reference & \\
\hline Hygienist 2 & & & $-7.3(-12.8,-1.8)$ & 0.011 & $-7.2(-12.4,-1.9)$ & 0.009 \\
\hline Hygienist 3 & & & $-4.8(-10.7,1.0)$ & 0.11 & $-6.1(-11.9,-0.4)$ & 0.037 \\
\hline Hygienist 4 & & & $-4.2(-0.1,0.2)$ & 0.23 & $-6.3(-13.7,1.0)$ & 0.09 \\
\hline Baseline PD (\# $\geq 4 \mathrm{~mm})$ & & & $0.1(0.01,0.2)$ & $<0.001$ & $0.2(0.1,0.2)$ & $<0.001$ \\
\hline Follow-up time (days) & & & $0.0(-0.1,0.2)$ & 0.54 & $0.0(-0.1,0.2)$ & 0.54 \\
\hline \multicolumn{7}{|l|}{ Sex } \\
\hline Male & & & & & Reference & \\
\hline Female & & & & & $4.1(-0.8,9.0)$ & 0.10 \\
\hline Age (years) & & & & & $0.2(0.0,0.4)$ & 0.041 \\
\hline BMI $\left(\mathrm{kg} / \mathrm{m}^{2}\right)$ & & & & & $-0.5(-1.0,0.0)$ & 0.038 \\
\hline Flossing (times/week) & & & & & $0.0(-0.5,0.6)$ & 0.89 \\
\hline BOP (\# sites) & & & & & $0.3(0.0,0.6)$ & 0.09 \\
\hline
\end{tabular}

${ }^{1}$ Regression of probing depth (number of sites $\geq 4 \mathrm{~mm}$ ) using low $(<1 \mathrm{~g} / \mathrm{kg} /$ day) and high $(\geq 1 \mathrm{~g} / \mathrm{kg} /$ day) protein intake as a categorical variable. Unstandardized regression coefficients (B) and 95\% confidence intervals (CI) are shown. Non-standard abbreviations: BOP, bleeding on probing; $\mathrm{PD}$, probing depth.

In this second model, patients who consumed $\geq 1 \mathrm{~g} / \mathrm{kg} /$ day of protein had significantly fewer numbers of sites with $\mathrm{PD} \geq 4 \mathrm{~mm}$ compared to patients who consumed $<1 \mathrm{~g} / \mathrm{kg}$ body weight/day (10 \pm 2 versus $16 \pm 1, p=0.018$ ) (Model 2, Table 2 and Figure 2a). Lastly, to control for potential confounders and to better understand the association between protein intake and PD, the confounders identified in Table 1 were added to the model: sex, BMI, flossing frequency, as well as age and BOP at follow-up as an objective measure of oral hygiene.

In the fully adjusted model, there continued to be a significant association between the consumption of $\geq 1 \mathrm{~g} / \mathrm{kg}$ body weight/day of protein and a reduction in the number of sites with PD $\geq 4 \mathrm{~mm}$ compared to patients who consumed $<1 \mathrm{~g} / \mathrm{kg}$ body weight/day $(8 \pm 2$ versus $18 \pm 2, p<0.001)$ (Model 3, Table 2 and Figure 2a). In patients who smoked, no significant differences in the number of sites with probing depths $\geq 4 \mathrm{~mm}$ were observed based on protein intake in any of the models (Table 3 and Figure $2 b$ ).

Table 3. Multiple linear regression of probing depth sites $\geq 4 \mathrm{~mm}$ after non-surgical periodontal therapy in patients who smoked ${ }^{1}$.

\begin{tabular}{|c|c|c|c|c|c|c|}
\hline & \multicolumn{2}{|l|}{ Model 1} & \multicolumn{2}{|c|}{ Model 2} & \multicolumn{2}{|c|}{ Model 3} \\
\hline & $B(95 \% \mathrm{CI})$ & $p$ & $B(95 \%$ CI $)$ & $p$ & $B(95 \%$ CI $)$ & $p$ \\
\hline $\begin{array}{l}\text { Protein intake } \\
<1 \mathrm{~g} / \mathrm{kg} \text { body } \\
\text { weight/day }\end{array}$ & Reference & & Reference & & Reference & \\
\hline $\begin{array}{l}\geq 1 \mathrm{~g} / \mathrm{kg} \text { body } \\
\text { weight/day }\end{array}$ & $-2.2(-18.3,13.8)$ & 0.77 & $-0.4(11.9,11.1)$ & 0.95 & $16.3(-1.4,34.0)$ & 0.066 \\
\hline
\end{tabular}


Table 3. Cont

\begin{tabular}{|c|c|c|c|c|c|c|}
\hline & \multicolumn{2}{|c|}{ Model 1} & \multicolumn{2}{|l|}{ Model 2} & \multicolumn{2}{|l|}{ Model 3} \\
\hline & $B(95 \% \mathrm{CI})$ & $p$ & $B(95 \% \mathrm{CI})$ & $p$ & $B(95 \% \mathrm{CI})$ & $p$ \\
\hline \multicolumn{7}{|l|}{ Hygienist } \\
\hline Hygienist 1 & & & Reference & & Reference & \\
\hline Hygienist 2 & & & $-18.2(-32.7,-3.8)$ & 0.017 & $-25.0(-44.7,-5.2)$ & 0.016 \\
\hline Hygienist 3 & & & $-7.0(-28.4,14.4)$ & 0.49 & $-9.8(-35.3,15.7)$ & 0.45 \\
\hline Hygienist 4 & & & $-20.7(-46.1,4.8)$ & 0.10 & $-26.2(-55.2,2.8)$ & 0.033 \\
\hline Baseline PD (\# $\geq 4 \mathrm{~mm})$ & & & $0.2(0.0,0.4)$ & 0.025 & $0.1(-0.2,0.3)$ & 0.38 \\
\hline Follow-up time (days) & & & $0.3(-0.1,0.6)$ & 0.17 & $0.0(-0.5,0.5)$ & 0.98 \\
\hline \multicolumn{7}{|l|}{ Sex } \\
\hline Male & & & & & Reference & \\
\hline Female & & & & & $-9.6(-27.1,7.9)$ & 0.30 \\
\hline Age (years) & & & & & $0.2(-0.6,0.9)$ & 0.60 \\
\hline BMI $\left(\mathrm{kg} / \mathrm{m}^{2}\right)$ & & & & & $0.3(-1.0,1.6)$ & 0.66 \\
\hline Flossing (times/week) & & & & & $-0.3(-1.3,0.7)$ & 0.47 \\
\hline BOP (\# sites) & & & & & $0.8(0.1,1.4)$ & 0.017 \\
\hline
\end{tabular}

${ }^{1}$ Regression of probing depth (number of sites $\geq 4 \mathrm{~mm}$ ) using low ( $<1 \mathrm{~g} / \mathrm{kg} /$ day) and high $(\geq 1 \mathrm{~g} / \mathrm{kg} /$ day) protein intake as a categorical variable. Unstandardized regression coefficients $(B)$ and 95\% confidence intervals $(\mathrm{CI})$ are shown. Non-standard abbreviations: BOP, bleeding on probing; PD, probing depth.

\section{Discussion}

A key finding from this study is the association between higher consumption of dietary protein $(\geq 1 \mathrm{~g} / \mathrm{kg}$ body weight/day) and a greater reduction in the number of sites with a PD $\geq 4 \mathrm{~mm}$ in patients who were non-smokers after SRP. Moreover, this relationship was strengthened by controlling for baseline PD, hygienist and time between treatment and follow-up. It was even further strengthened after accounting for additional confounding factors such as age, sex, BMI, flossing frequency and BOP. While there is little literature available on the relationship between dietary protein and periodontal disease in non-smokers, that which is available supports the current findings. For example, feeding milk basic protein, containing whey protein and other potential bioactives, improved healing in a rat model of periodontal disease [31]. Periodontal disease was induced in rats by placing a ligature on the second maxillary molar for 20 days. The ligature was then removed, and varying levels of milk basic protein were added into the control diet at a level of $0.2 \%$ or $1.0 \%$ MBP while keeping the total level of protein similar among diets. The rats fed the diet containing a higher level of MPB (1.0\%) had greater alveolar bone regeneration following 90 days compared to rats fed the control diet or the diet containing $0.2 \%$ MBP.

Additional evidence supporting a relationship between dietary protein and periodontal disease comes from data from the fifth and sixth Korean National Health and Nutrition Examination Survey $(n=9798)$, which found that consuming $\geq 7$ servings of dairy products per week was associated with a $24 \%$ lower prevalence of periodontal disease after controlling for confounding factors including calcium intake, BMI and smoking status [29]. Given that dairy foods tend to be high in protein, the authors hypothesized that whey proteins may prevent alveolar bone loss and attenuate periodontal disease. Similar findings were reported in a cohort study using Danish Health Examination Survey data $(n=3287)$ which found adults consuming $\geq 9.6 \mathrm{~g}$ of whey/day and/or $\geq 32 \mathrm{~g}$ casein/day had a lower likelihood of severe periodontal disease as defined by the American Academy of Periodontology [30,38].

A similar relationship between protein intake and the number of sites with PD $\geq 4 \mathrm{~mm}$ was not observed in patients who smoked. This may be a result of smoking having negative effects on oral health and healing-this was previously shown for other nutrients [18]. Smoking is one of the largest risk factors for periodontal disease and is thought to impact periodontal health through various mechanisms, including decreased vascular flow, decreased lymphocyte proliferation, and impairing neutrophil function, thus compromising 
wound healing $[11,13,15,39]$. However, it is important to note that there were relatively few patients who smoked within the study and as such, this specific analysis was underpowered but helps inform the design of future studies. Based on the results of this study, a retrospective power calculation was performed. Detecting a difference in the PD depth of 2.2 sites with a standard deviation of $18.0,(\alpha=0.05, \beta=0.80)$ would require a sample size of $n=1050$ per group, assuming a relationship exists in smokers. Given the small difference in PD seen in smokers, it is likely that either no relationship exists or that the effect size is too small to be clinically meaningful.

It is possible that protein has both direct and indirect effects on periodontal health. One possible explanation of the observed relationship between probing depth and protein intake could be due to its direct effects on wound repair. For example, studies have found that protein malnutrition leads to delayed wound healing [40]. Moreover, in a randomized clinical trial of elderly home-nursed patients, consuming a nutrient- and protein-dense supplement resulted in improved wound healing [41]. The level and quality of protein intake are known to affect collagen deposition and other factors that result in delayed wound healing [39-42]. However, no studies have specifically studied protein intake and oral healing. Additionally, given that periodontal disease can result in a loss of bone and teeth, the osteogenic effects of protein are hypothesized to contribute to long-term periodontal health; however, these effects might not be expected to contribute directly to changes in probing depth during the 8 to 16 week follow-up. Studies of protein intake and bone health indicate that there is little benefit of increasing protein intake beyond levels of $0.8-1.3 \mathrm{~g} / \mathrm{kg}$ body weight/day in healthy adults-and no detrimental effects of such higher protein intakes to bone mineral density or fracture risk provided calcium intake is at the recommended level [28]. However, levels of protein intake below $0.8 \mathrm{~g} / \mathrm{kg}$ body weight/day could potentially have negative implications for bone health and periodontal disease.

\section{Strengths and Limitations}

One of the strengths of this study was that there were no significant differences in baseline periodontal outcomes between protein intake groups. Given that baseline PD was associated with periodontal outcomes 8 to 16 weeks post-SRP in our original study [18], this reduces the likelihood that baseline periodontal health served as a confounding factor in this study. Additionally, there were no differences in participant age, former smoking status, comorbidities, brushing frequency, electric toothbrush use, professional cleaning frequency and previous periodontal therapy between protein intake groups regardless of smoking status. The study also included approximately equal proportions of male and female participants.

Some of the limitations are the use of FFQ to measure dietary intake, multiple hygienists performing periodontal examinations, variation in the length of time before SRP and follow-up time after SRP, and potential confounding variables such as dental hygiene practices. Due to the tendency of FFQs to overestimate food intakes [43], caution should be used when interpreting intake levels derived from this study and comparisons to the RDA. Additionally, the FFQ used was unable to differentiate between dairy, animal, and plant proteins. Thus, we are unable to draw specific conclusions based on protein type. The effects of multiple examiners were minimized by calibrating hygienists and performing statistical control for this variable. The variation in the length of time prior to and after SRP reflect the real-life situation of clinical practice, in which patients need to find time in busy schedules for these appointments. Baseline examinations occurred 1 to 19 weeks prior to SRP, and follow-up time ranged from 8 to 16 weeks, which was the standard of care at the time of the study. In patients who were non-smokers, flossing frequency was significantly higher in the group who consumed $\geq 1 \mathrm{~g}$ protein $/ \mathrm{kg}$ body weight/day. While this may serve as a confounding factor, it is unlikely to have a large effect, given that all other oral hygiene variables showed no significant difference between groups, which suggests overall that patients had relatively similar oral hygiene behaviors. Additionally, including flossing 
frequency as a covariate in statistical models had minimal effect on the strength of the associations observed. The small sample size for the group of patients who were smokers is a limitation, though it was also encouraging that there were far fewer participants who smoked given the known detriment that smoking has on overall health.

\section{Conclusions}

This study shows a positive association between protein intakes $\geq 1 \mathrm{~g} / \mathrm{kg}$ body weight/day and better periodontal healing following SRP in patients who do not smoke, but not in patients who smoke. Albeit there were few patients who were current smokers, so this association requires verification. Future dietary intervention studies during the post-SRP healing phase are warranted in order to determine the potential benefits of protein intake as an adjunct to SRP. Additionally, long-term studies should be carried out to measure the relationship between dietary protein intake, tooth loss and alveolar bone loss, as these measures may be better indicators of the long-term benefit of higher protein intakes for periodontal health.

Supplementary Materials: The following are available online at https:/ /www.mdpi.com/article/10 .3390/nu13113722/s1, Table S1: descriptive statistics and clinical parameters of excluded participants.

Author Contributions: Conceptualization, D.W.D., P.C.F. and W.E.W.; methodology, D.W.D.; formal analysis, D.W.D., H.E.Y. and J.R.B.; investigation, D.W.D.; resources, P.C.F. and W.E.W.; data curation, D.W.D., H.E.Y. and J.R.B.; writing—original draft preparation, D.W.D. and W.E.W.; writing—review and editing, H.E.Y., J.R.B., D.W.D., W.E.W. and P.C.F.; visualization, D.W.D. and H.E.Y.; supervision, P.C.F. and W.E.W.; project administration, D.W.D., P.C.F. and W.E.W. All authors have read and agreed to the published version of the manuscript.

Funding: Funding was provided by start-up funding to W.E.W. from Brock University. D.W.D. held a Frederick Banting and Charles Best Canada Graduate Scholarship. W.E.W. holds a Canada Research Chair in Bone and Muscle Development. H.E.Y. held an Ontario Graduate Scholarship.

Institutional Review Board Statement: The study was conducted according to the guidelines of the Declaration of Helsinki and approved by the Bioscience Research Ethics Board of Brock University (12-068-WARD, November 2012).

Informed Consent Statement: Informed consent was obtained from all subjects involved in the study.

Data Availability Statement: The data presented in this study are available upon request from the corresponding authors. The data are not publicly available due to ethics restrictions.

Acknowledgments: The authors are grateful to the clinical team at PCF's Periodontal Wellness and Implant Surgery Clinic, who assisted with patient recruitment, the measurement of clinical outcomes, and the collection of samples.

Conflicts of Interest: The authors declare no conflict of interest. The funders had no role in the design of the study; in the collection, analyses, or interpretation of data; in the writing of the manuscript, or in the decision to publish the results.

\section{References}

1. Canadian Dental Association. Available online: https://www.cda-adc.ca/en/oral_health/faqs/gum_diseases_faqs.asp (accessed on 3 April 2020).

2. GBD 2016 Disease and Injury Incidence and Prevalence Collaborators. Global, regional, and national incidence, prevalence, and years lived with disability for 328 diseases and injuries for 195 countries, 1990-2016: A systematic analysis for the Global Burden of Disease Study 2016. Lancet 2017, 390, 1211-1259. [CrossRef]

3. Tonetti, M.S.; Jepsen, S.; Jin, L.; Otomo-Corgel, J. Impact of the global burden of periodontal diseases on health, nutrition and wellbeing of mankind: A call for global action. J. Clin. Periodontol. 2017, 44, 456-462. [CrossRef] [PubMed]

4. Eke, P.I.; Dye, B.A.; Wei, L.; Thornton-Evans, G.O.; Genco, R.J. Prevalence of periodontitis in adults in the United States: 2009 and 2010. J. Dent. Res. 2012, 91, 914-920. [CrossRef]

5. Billings, M.; Holtfreter, B.; Papapanou, P.N.; Mitnik, G.L.; Kocher, T.; Dye, B.A. Age-dependent distribution of periodontitis in two countries: Findings from NHANES 2009 to 2014 and SHIP-TREND 2008 to 2012. J. Clin. Periodontol. 2018, 45, S130-S148. [CrossRef] 
6. Chapple, I.L.C.; Bouchard, P.; Cagetti, M.G.; Campus, G.; Carra, M.C.; Cocco, F.; Nibali, L.; Hujoel, P.; Laine, M.L.; Lingstrom, P.; et al. Interaction of lifestyle, behaviour or systemic diseases with dental caries and periodontal diseases: Consensus report of group 2 of the joint EFP/ORCA workshop on the boundaries between caries and periodontal diseases. J. Clin. Periodontol. 2017, 44, S39-S51. [CrossRef] [PubMed]

7. Chapple, I.L.C.; van der Weijden, F.; Doerfer, C.; Herrera, D.; Shapira, L.; Polak, D.; Madianos, P.; Louropoulou, A.; Machtei, E.; Donos, N.; et al. Primary prevention of periodontitis: Managing gingivitis. J. Clin. Periodontol. 2015, 42, 71-76. [CrossRef] [PubMed]

8. Sanz, M.; Herrera, D.; Kebschull, M.; Chapple, I.; Jepsen, S.; Beglundh, T.; Sculean, A.; Tonetti, M.S.; EFP Workshop Participants and Methodological Consultants. Treatment of Stage I-III Periodontitis-The EFP S3 Level Clinical Practice Guideline. J. Clin. Periodontol. 2020, 47 (Suppl. 22), 4-60. [CrossRef] [PubMed]

9. Damgaard, C.; Kantarci, A.; Holmstrup, P.; Hasturk, H.; Nielsen, C.H.; van Dyke, T.E. Porphyromonas Gingivalis-induced production of reactive oxygen species, tumor necrosis factor- $\alpha$, interleukin- 6 , CXCL8 and CCL2 by neutrophils from localized aggressive periodontitis and healthy donors: Modulating actions of red blood cells and resolvin E1. J. Periodontal. Res. 2017, 52, 246-254. [CrossRef] [PubMed]

10. Reis, C.; da Costa, A.V.; Guimarães, J.T.; Tuna, D.; Braga, A.C.; Pacheco, J.J.; Arosa, F.A.; Salazar, F.; Cardoso, E.M. Clinical improvement following therapy for periodontitis: Association with a decrease in IL-1 and IL-6. Exp. Ther. Med. 2014, 8, 323-327. [CrossRef] [PubMed]

11. Rom, O.; Avezov, K.; Aizenbud, D.; Reznick, A.Z. Cigarette smoking and inflammation revisited. Respir. Physiol. Neurobiol. 2013, 187, 5-10. [CrossRef]

12. Barbieri, S.S.; Zacchi, E.; Amadio, P.; Gianellini, S.; Mussoni, L.; Weksler, B.B.; Tremoli, E. Cytokines present in smokers' serum interact with smoke components to enhance endothelial dysfunction. Cardiovasc. Res. 2011, 90, 475-483. [CrossRef] [PubMed]

13. Naji, A.; Edman, K.; Holmlund, A. Influence of smoking on periodontal healing one year after active treatment. J. Clin. Periodontol. 2020, 47, 343-350. [CrossRef] [PubMed]

14. Boström, L.; Linder, L.E.; Bergström, J. Influence of smoking on the outcome of periodontal surgery: A 5-year follow-up. J. Clin. Periodontol. 1998, 25, 194-201. [CrossRef]

15. Heasman, L.; Stacey, F.; Preshaw, P.M.; McCracken, G.I.; Hepburn, S.; Heasman, P.A. The effect of smoking on periodontal treatment response: A review of clinical evidence. J. Clin. Periodontol. 2006, 33, 241-253. [CrossRef] [PubMed]

16. Lau, B.Y.; Johnston, B.D.; Fritz, P.C.; Ward, W.E. Dietary strategies to optimize wound healing after periodontal and dental implant surgery: An evidence-based review. Open Dent. J. 2013, 7, 36-46. [CrossRef] [PubMed]

17. Iwasaki, M.; Manz, M.C.; Taylor, G.W.; Yoshihara, A.; Miyazaki, H. Relations of serum ascorbic acid and $\alpha$-tocopherol to periodontal disease. J. Dent. Res. 2012, 91, 167-172. [CrossRef] [PubMed]

18. Dodington, D.W.; Fritz, P.C.; Sullivan, P.J.; Ward, W.E. Higher intakes of fruits and vegetables, $\beta$-Carotene, Vitamin C, $\alpha$ Tocopherol, EPA, and DHA are positively associated with periodontal healing after nonsurgical periodontal therapy in nonsmokers but not in smokers. J. Nutr. 2015, 145, 2512-2519. [CrossRef]

19. Abou Sulaiman, A.E.; Shehadeh, R.M.H. Assessment of total antioxidant capacity and the use of vitamin C in the treatment of non-smokers with chronic periodontitis. J. Periodontol. 2010, 81, 1547-1554. [CrossRef] [PubMed]

20. Martinon, P.; Fraticelli, L.; Giboreau, A.; Dussart, C.; Bourgeois, D.; Carrouel, F. Nutrition as a key modifiable factor for periodontitis and main chronic diseases. J. Clin. Med. 2021, 10, 197. [CrossRef] [PubMed]

21. O'Connor, J.L.P.; Milledge, K.L.; O'Leary, F.; Cumming, R.; Eberhard, J.; Hirani, V. Poor dietary intake of nutrients and food groups are associated with increased risk of periodontal disease among community-dwelling older adults: A systematic literature review. Nutr. Rev. 2020, 78, 175-188. [CrossRef]

22. Baima, G.; Romandini, M.; Citterio, F.; Romano, F.; Aimetti, M. Periodontitis and Accelerated Biological Aging: A Geroscience Approach. J. Dent. Res. 2021. Advance online publication. [CrossRef] [PubMed]

23. Clark, D.; Kotronia, E.; Ramsay, S.E. Frailty, aging, and periodontal disease: Basic biologic considerations. Periodontol. 2000 2021, 87, 143-156. [CrossRef] [PubMed]

24. McClave, S.A.; Martindale, R.G.; Vanek, V.W.; McCarthy, M.; Roberts, P.; Taylor, B.; Ochoa, J.B.; Napolitano, L.; Cresci, G. Guidelines for the provision and assessment of nutrition support therapy in the adult critically ill patient. J. Parenter. Enter. Nutr. 2009, 33, 277-316. [CrossRef] [PubMed]

25. Phillips, S.M. Determining the protein needs of "older" persons one meal at a time. Am. J. Clin. Nutr. 2017, 105, 291-292. [CrossRef] [PubMed]

26. Baum, J.I.; Kim, I.Y.; Wolfe, R.R. Protein Consumption and the elderly: What is the optimal level of intake? Nutrients 2016, 8, 359. [CrossRef] [PubMed]

27. Bauer, J.; Biolo, G.; Cederholm, T.; Cesari, M.; Cruz-Jentoft, A.J.; Morley, J.E.; Phillips, S.; Sieber, C.; Stehle, P.; Teta, D.; et al. Evidence-based recommendations for optimal dietary protein intake in older people: A position paper from the Prot-Age study group. J. Am. Med. Dir. Assoc. 2013, 14, 542-559. [CrossRef] [PubMed]

28. Darling, A.L.; Manders, R.J.F.; Sahni, S.; Zhu, K.; Hewitt, C.E.; Prince, R.L.; Millward, D.J.; Lanham-New, S.A. Dietary protein and bone health across the life-course: An updated systematic review and meta-analysis over 40 years. Osteoporos. Int. 2019, 30, 741-761. [CrossRef] [PubMed] 
29. Lee, K.; Kim, J. Dairy food consumption is inversely associated with the prevalence of periodontal disease in Korean adults. Nutrients 2019, 11, 1035. [CrossRef] [PubMed]

30. Adegboye, A.R.A.; Boucher, B.J.; Kongstad, J.; Fiehn, N.E.; Christensen, L.B.; Heitmann, B.L. Calcium, Vitamin D, casein and whey protein intakes and periodontitis among Danish adults. Public Health Nutr. 2016, 19, 503-510. [CrossRef] [PubMed]

31. Seto, H.; Toba, Y.; Takada, Y.; Kawakami, H.; Ohba, H.; Hama, H.; Horibe, M.; Nagata, T. Milk basic protein increases alveolar bone formation in rat experimental periodontitis. J. Periodontal. Res. 2007, 42, 85-89. [CrossRef] [PubMed]

32. Wiebe, C.; Putnins, E. The Periodontal Disease Classification System of the American Academy of Periodontology—An Update. J. Can. Dent. Assoc. 2000, 66, 594-597. [PubMed]

33. Papapanou, P.N.; Sanz, M.; Buduneli, N.; Dietrich, T.; Feres, M.; Fine, D.H.; Flemmig, T.F.; Garcia, R.; Giannobile, W.V.; Graziani, F.; et al. Periodontitis: Consensus report of workgroup 2 of the 2017 World Workshop on the Classification of Periodontal and Peri-Implant Diseases. J. Periodontol. 2018, 89, S173-S182. [CrossRef] [PubMed]

34. O'Leary, T.J.; Drake, R.B.; Naylor, J.E. The plaque control record. J. Periodontol. 1972, 43, 38. [CrossRef] [PubMed]

35. Block, G.; Woods, M.; Potosky, A.; Clifford, C. Validation of a self-administered diet history questionnaire using multiple diet records. J. Clin. Epidemiol. 1990, 43, 1327-1335. [CrossRef]

36. Willett, W.C.; Howe, R. Adjustment for total energy intake in epidemiologic studies. Am. J. Clin. Nutr. 1997, 65, 1220S-1228S. [CrossRef]

37. Patel, R.A.; Wilson, R.F.; Palmer, R.M. The effect of smoking on periodontal bone regeneration: A systematic review and meta-analysis. J. Periodontol. 2012, 83, 143-155. [CrossRef] [PubMed]

38. Page, R.C.; Eke, P.I. Case definitions for use in population-based surveillance of periodontitis. J. Periodontol. 2007, 78, 1387-1399. [CrossRef] [PubMed]

39. Tomar, S.L.; Asma, S. Smoking-attributable periodontitis in the United States: Findings from NHANES III. J. Periodontol. 2000, 71, 743-751. [CrossRef]

40. Yamane, T.; Konno, R.; Iwatsuki, K.; Oishi, Y. Negative Effects of a Low-Quality Protein Diet on Wound Healing via Modulation of the MMP2 activity in rats. Amino Acids 2020, 52, 505-510. [CrossRef] [PubMed]

41. Collins, C.E.; Kershaw, J.; Brockington, S. Effect of nutritional supplements on wound healing in home-nursed elderly: A randomized trial. Nutrition 2005, 21, 147-155. [CrossRef] [PubMed]

42. Wolfe, R.R.; Miller, S.L.; Miller, K.B. Optimal protein intake in the elderly. Clin. Nutr. 2008, 27, 675-684. [CrossRef] [PubMed]

43. Shu, X.O.; Yang, G.; Jin, F.; Liu, D.; Kushi, L.; Wen, W.; Gao, Y.T.; Zheng, W. Validity and reproducibility of the food frequency questionnaire used in the Shanghai Women's Health Study. Euro. J. Clin. Nutr. 2004, 58, 17-23. [CrossRef] 